\title{
PERSEPSI DAN PREFERENSI TERHADAP SIKAP NASABAH PEMBIAYAAN MUSYARAKAH DI BRI SYARIAH
}

\author{
Jujun Jamaludin \\ Perbankan Syariah, Universitas Ma'soem \\ jujunjamaludin88@gmail.com \\ Dadang Dimyati \\ Perbankan Syariah, Universitas Ma'soem \\ Dadangdimyati.mm.almasoem@gmail.com \\ Widiawati \\ Manajemen Keuangan Syariah, UIN Sunan Gunung Djati Bandung \\ widiawati@uinsgd.ac.id \\ Anisa Ristanti \\ Perbankan Syariah, Universitas Ma'soem \\ anisaristanti2017ps@gmail.com
}

\begin{abstract}
Abstrak
Latarbelakang penelitian ini adalah fluktuatifnya jumlah nasabah produk pembiayaan musyarakah di BRI Syariah KC Suniaraja Bandung. Penelitian ini bertujuan untuk mengetahui pengaruh persepsi dan preferensi terhadap Sikap Nasabah Pembiayaan Musyarakah di BRI Syariah KC Suniaraja Bandung baik secara parsial maupun simultan. Objek penelitian pada penelitian ini adalah persepsi, preferensi dan Sikap Nasabah Pembiayaan Musyarakah di BRI Syariah KC Suniaraja Bandung. Penelitian ini adalah jenis kuantitatif dengan metode analisis deskriptif. Populasi berjumlah 112 nasabah, dengan 53 orang yang menjadi sampel. Untuk mendapatkan data, penelitia menggunakan sumber data primer yaitu angket dan disebar ke 53 responden. Hasil penelitian menunjukkan; pertama, secara parsial persepsi berpengaruh terhadap sikap nasabah pembiayaan musyarakah BRI Syariah KCP Suniaraja di mana kontribusi pengaruhnya sebesar 21\%. Kedua, secara parsial preferensi berpengaruh juga terhadap sikap nasabah pembiayaan musyarakah BRI Syariah KCP Suniaraja dengan kontribusi pengaruh 20.9\%. Ketiga, secara simultan persepsi dan preferensi terhadap sikap nasabah pembiayaan musyarakah BRI Syariah KCP Suniaraja denngan kontribusi pengaruh 28.6\%. Implikasi dari penelitian ini adalah BRI Syariah yang kini telah berubah menjadi Bank Syariah Indonesia dapat menjadikan hasil ini sebagai acuan karena untuk dapat terus meningkatkan jumlah nasabah pembiayaan maka BSI dapat melakukan riset untuk mengetahui preferensi dan persepsi masayrakat terkait dengan pembiayaan musyarakah.
\end{abstract}

Kata Kunci : Persepsi, Preferensi dan Sikap Nasabah Pembiayaan Musyarakah

\begin{abstract}
The background of this research is the fluctuating number of customers of musyarakah financing products at BRI Syariah KC Suniaraja Bandung. This study aims to determine the effect of perceptions and preferences on Customer Attitudes in Musyarakah Financing at BRI Syariah KC Suniaraja Bandung,
\end{abstract}


either partially or simultaneously. The object of this research is the perceptions, preferences and attitudes of Musyarakah Financing Customers at BRI Syariah KC Suniaraja Bandung. This research is a quantitative type with descriptive analysis method. The population is 112 customers, with 53 people being the sample. To obtain data, the research used primary data sources, namely questionnaires and distributed to 53 respondents. The results showed; First, partially, perceptions affect the attitudes of customers of BRI Syariah KCP Suniaraja Musyarakah financing where the contribution of the influence is 21\%. Second, partially preference also affects the attitude of BRI Syariah KCP Suniaraja Musyarakah financing customers with a contribution of 20.9\% influence. Third, simultaneously the perception and preference of the attitude of BRI Syariah KCP Suniaraja Musyarakah financing customers with a contribution of 28.6\% influence. The implication of this research is that BRI Syariah which has now turned into Bank Syariah Indonesia can use this result as a reference because to be able to continue to increase the number of financing customers, BSI can conduct research to find out the preferences and perceptions of the community related to musyarakah financing.

\section{Keywords : Perception, Preference and Musyarakah Financing Customer Attitude}

\section{Pendahuluan}

Pembiayaan dan investasi yang sesuai dengan syariat islam pada perbankan syariah diharapkan mampu mempercepat pertumbuhan ekonomi sehingga berimplikasi pada masyarakat yang makmur dan sejahtera dari segi ekonomi. Mengacu pada fungsi bank syariah, pihak yang kekurangan dana dan kelebihan dana dapat terjembatani melalui keberadaan bank syariah ini, yaitu dengan pengajuan pembiayaan dengan sistem bagi hasil. (Sari, 2020)

Di Indonesia, sistem bagi hasil pada sistem pembiayaan bank syariah masih belum dipahami sepenuhnya. Banyak nasabah yang tidak mengetahui esensi, prinsip, mekanisme, syarat dan rukun dari implementasi fikih muamalah ini. Selain itu, saat ini pembiayaan bagi hasil yang dilakukan oleh bank syariah masih berpihak pada sektor rill, sehingga pembiayaan dengan sistem bagi hasil ini masih mengutamakan dan didominasi oleh sektor rill. (Wakhidah, 2012).

Sistem bagi hasil mengedepankan aspek keadilan dalam pelaksanaannya. Ini menjadi alternatif bagi masyarakat dan bank agar saling mendapatkan keuntungan satu sama lain, kemudian mengutamakan nilai-nilai kebersamaan, dan persaudaraan, juga memperhatikan etika dan norma investasi dalam syariat islam. (Miftahuddin, 2019).

Salah satu bank syariah yang ada di Indonesia yaitu BRI Syariah. BRI Syariah dalam menjalankan kegiatan usahanya mencakup penghimpunan, jasa-jasa perbankan dan pembiayaan. Salah satu produk pembiayaan yaitu produk akad musyarakah yang merupakan produk lending bank yang termasuk dalam kategori produk pembiayaan yang complicated. Segmentasi nasabah yang menggunakan akad pembiayaan musyarakah umumnya terdiri atas nasabah korporasi/ komersial yang membutuhkan dana modal kerja yang continue dan bersifat revolving (Ikatan Bankir Indonesia, 2015).

Pembiayaan dengan sistem bagi hasil menggunakan akad musyarakah masih perlu pengembangan agar dikenal masyarakat. Upaya-upaya yang dapat dilakukan meningkatkan literasi dan inklusi terkait mekanisme, sistem, kelebihan, dan kekurangan dari produk pembiayaan ini. Agar upaya tersebut dapat berhasil maka informasi terkait 
karakteristik produk, dan preferensi serta persepsi nasabah terhadap pembiayaan musyarakat sangat diperlukan.

Indikator yang digunakan untuk mengukur persepsi adalah pegetahuan dan pengaruh kebutuhan. Dengan adanya pengetahuan seorang nasabah terhadap produk pembiayaan, maka nasabah memutusukan atas apa yang menjadi pilihan kecenderungan dan kesukaan terhadap produk pembiayaan, sehingga nasabah akan mempertimbangkan bagaimana alternatif untuk memenuhi kebutuhan yang kemudian memutuskan pilihan mengambil produk pembiayaan musyarakah. Adapun faktor yang dapat mempengaruhi nasabah dalam menentukan pilihan yaitu dapat dinilai dari tingkat persepsi (pengetahuan). Pengetahuan merupakan hasil dari tahu, dengan informasi berbagai produk dan fasilitas yang diberikan kepada nasabah diharapkan dapat memberikan kemudahan bagi nasabah untuk memilih produk bank syariah (Notoatmodjo, 2003).

Selain persepsi, indikator lain yang dapat meningkatkan sikap nasabah terhadap pembiayaan musyarakah ialah preferensi. Menurut Kotler preferensi konsumen menunjukkan kesukaan konsumen dari berbagai pilihan produk jasa yang ada ( Kotler, 1997).Preferensi merupakan indikator dari keterbukaan informasi sehingga dapat menjadi umpan balik yang positif dari nasabah ataupun prioritas/ pilihan, kecenderungan dan kesukaan terhadap suatu objek.

Menurut Nugroho J. Setiadi, preferensi terhadap barang dan jasa dipengaruhi oleh empat faktor, yaitu faktor kebudayaan (budaya, subbudaya, kelas sosial), faktor sosial (kelompok referensi, keluarga, peran), faktor pribadi (umur, pekerjaan, gaya hidup, kepribadian), dan faktor psikologis (motivasi). (Setiadi, 2019)

Pilihan nasabah pembiayaan musyarakah di BRI Syariah KC Suniaraja Bandung sebagai responden penelitian, karena BRI Syariah merupakan salah satu bank yang mempunyai produk pembiayaan musyarakah dengan prinsip bagi hasil sesuai ajaran islam yang berlandaskan Al-Qur'an dan Hadits. Berikut adalah data jumlah nasabah pembiayaan musyarakah di BRI Syariah KC Suniaraja Bandung dalam kurun waktu lima tahun terakhir dapat dilihat pada tabel berikut :

Tabel 1 Data nasabah pembiayaan musyarakah di BRI Syariah Kantor Cabang Suniaraja Bandung

\begin{tabular}{|c|c|c|}
\hline Tahun & Jumlah Nasabah & Persentase \\
\hline 2016 & 103 & - \\
\hline 2017 & 124 & $0,20 \%$ \\
\hline 2018 & 135 & $0,08 \%$ \\
\hline 2019 & 117 & $(0,13 \%)$ \\
\hline 2020 & 112 & $(0,04 \%)$ \\
\hline
\end{tabular}

Sumber : BRI Syariah KC Suniaraja Bandung 2021

Berdasarkan tabel diatas, dapat dilihat bahwa jumlah nasabah pembiayaan musyarakah di BRI Syariah KC Suniaraja Bandung pada lima tahun terakhir mengalami fluktuasi, pada tahun 2016 sampai 2017 mengalami kenaikan sebesar 0,20\%, pada tahun 2018 terjadi kenaikan sebesar 0,08\%, namun pada tahun 2019 mengalami penurunan sebesar $0,13 \%$, dan tahun 2020 terjadi penurunan lagi sebesar $0,04 \%$.

Maka dari itu, artikel ini bertujuan untuk menganalisis pengaruh persepsi dan preferensi terhadap sikap nasabah pembiayaan musyarakah pada BRI Syariah Kantor 
Cabang Suniaraja, Berdasarkan latar belakang masalah dan tujuan penelitian ini, maka dibuatlah sebuah hipotesis. Hipotesis merupakan jawaban sementara atas permasalahan yang terdapat pada rumusan masalah penelitian. Berdasarkan kajian teoritis yang telah diuraikan diatas maka hipotesis dalam penelitian ini adalah:

a. Persepsi terhadap Sikap Nasabah Pembiayaan Musyarakah

H1: Persepsi berpengaruh terhadap sikap nasabah pembiayaan musyarakah

b. Preferensi terhadap Sikap Nasabah Pembiayaan Musyarakah

H2: Preferensi berpengaruh terhadap sikap nasabah pembiayaan musyarakah

c. Persepsi dan Preferensi terhadap Sikap Nasabah Pembiayaan Musyarakah

H3: Persepsi dan Preferensi berpengaruh terhadap sikap nasabah pembiayaan musyarakah

\section{Metode}

Artikel ini menggunakan metode deskriptif kuantitatif dalam penjabaran hasil dan pembahasannya. Populasi adalah sekelompok manusia yang berada pada satu wilayah tertentu yang kemudian dipelajari karakteristik dan kualitasnya sehingga dapat dijadikan subjek penelitian (Sugiyono, 2008). Populasi yang digunakan dalam penelitian ini yaitu 112 nasabah pembiayaan musyarakah BRI Syariah KC Suniaraja Bandung tahun 2020.

Sampel adalah sekelompok manusia dari populasi yang memenuhi kriteria yang telah ditentukan (Sugiyono, 2008). Pengambilan sampel pada penelitian ini diambil dengan teknik probability sampling, Sedangkan jenis sampel yang digunakan yaitu simple random sampling. Simple random sampling yaitu suatu pengambilan sampel anggota populasi yang dilakukan secara acak dan tidak memperhatikan strata yang tercantum pada populasi tersebut (Siyoto, 2015).

Berikut pengambilan data sampel menggunakan rumus slovin:

$$
\begin{aligned}
& \mathrm{n}=\frac{\mathrm{N}}{1+\mathrm{Ne}^{2}} \\
& \mathrm{n}=\frac{112}{1+112(10 \%)^{2}} \\
& \mathrm{n}=\frac{112}{1+112(0,1)^{2}} \\
& \mathrm{n}=\frac{112}{1+1,12} \\
& \mathrm{n}=\frac{112}{2,12} \\
& \mathrm{n}=52,8 \\
& \mathrm{n}=53
\end{aligned}
$$

Dengan demikian maka jumlah sampel yang harus diambil yaitu 53 nasabah.

Berikut operasional variabel penelitian ini:

Tabel 2 Operasional Variabel

Operasional Variabel

\begin{tabular}{|c|c|c|c|c|}
\hline No & Variabel & Indikator & Alat Ukur & Skala \\
\hline 1. & $\begin{array}{c}\text { Persepsi } \\
\text { X1 }\end{array}$ & 1. Pengetahuan & a. Informasi yang didapatkan & Ordinal \\
& & & b. Sumber informasi yang didapatkan & \\
\hline
\end{tabular}




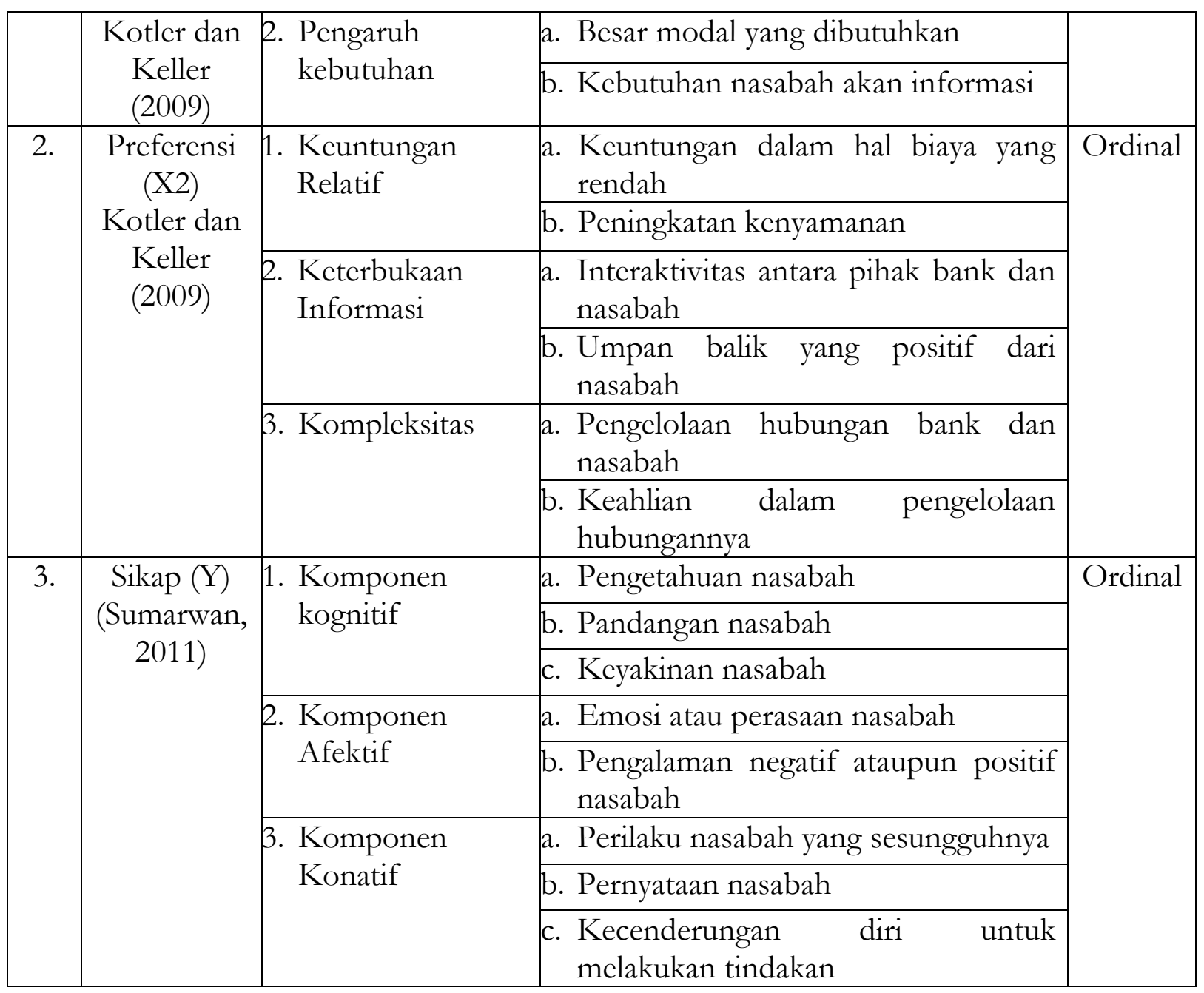

Sumber: Hasil Penelitian 2021

Selanjutnya, sumber data berasala dari data primer di mana didapatkan langsung dari sumber pertama menggunakan angket. Teknik analisis data menggunakan analisis regresi dan pengujian hipotesis, selain itu juga untuk menguji keabsahan data maka dilakukan uji validitas dan reliabilitas serta asumsi klasik.

\section{Hasil dan Pembahasan}

Hasil penelitian dan pembahasan ini menggunakan software SPSS versi 23, kemudian dijabarkan untuk diketahui bagaimana pengaruh persepsi dan preferensi nasabah pembiayaan musyarakah di BRI Suniaraja. Berikut penjelasan dari setiap hasil uji SPSS tersebut.

\subsection{Uji Validitas}

\section{Uji Validitas Variabel Persepsi}

Berikut hasil uji validitas untuk variabel X1 yaitu Persepsi:

Tabel 3 Uji Validitas Persepsi

\begin{tabular}{|c|c|c|c|}
\hline No. Item & R hitung & R tabel & Keterangan \\
\hline X1.1 & 0,830 & 0,279 & Valid \\
\hline X1.2 & 0,815 & 0,279 & Valid \\
\hline X1.3 & 0,706 & 0,279 & Valid \\
\hline
\end{tabular}


\begin{tabular}{l|l|l|l} 
X1.4 & 0,570 & 0,279 & Valid
\end{tabular}

Sumber: Hasil output SPSS for windows versi 23

Berdasarkan tabel diatas dapat disimpulkan bahwa pada uji validitas diketahui pernyataan dalam kuesioner Persepsi, karena rhitung $>\mathrm{r}_{\text {tabel }}$.

\section{Uji Validitas Variabel Preferensi}

Berikut hasil uji validitas untuk variabel X2 yaitu Preferensi:

Tabel 4 Uji Validitas Preferensi

\begin{tabular}{|c|c|c|c|}
\hline No. Item & R hitung & R tabel & Keterangan \\
\hline X2.1 & 0,453 & 0,279 & Valid \\
\hline X2.2 & 0,581 & 0,279 & Valid \\
\hline X2.3 & 0,620 & 0,279 & Valid \\
\hline X2.4 & 0,627 & 0,279 & Valid \\
\hline X2.5 & 0,618 & 0,279 & Valid \\
\hline X2.6 & 0,599 & 0,279 & Valid \\
\hline
\end{tabular}

Sumber: Hasil output SPSS for windows versi 23

Berdasarkan tabel diatas dapat disimpulkan bahwa pada uji validitas diketahui 6 pernyataan dalam kuesioner Preferensi, karena $r_{\text {hitung }}>\mathrm{r}_{\text {tabel. }}$

\section{Uji Validitas Variabel Sikap Nasabah}

Adapun hasil perhitungan uji validitas untuk Sikap Nasabah dapat dilihat pada tabel berikut:

Tabel 5 Uji Validitas Sikap Nasabah

\begin{tabular}{|c|c|c|c|}
\hline No. Item & R hitung & R tabel & Keterangan \\
\hline Y.1 & 0,519 & 0,279 & Valid \\
\hline Y.2 & 0,557 & 0,279 & Valid \\
\hline Y.3 & 0,468 & 0,279 & Valid \\
\hline Y.4 & 0,583 & 0,279 & Valid \\
\hline Y.5 & 0,652 & 0,279 & Valid \\
\hline Y.6 & 0,441 & 0,279 & Valid \\
\hline Y.7 & 0,697 & 0,279 & Valid \\
\hline Y.8 & 0,743 & 0,279 & Valid \\
\hline
\end{tabular}

Sumber: Hasil output SPSS for windows versi 23

Berdasarkan tabel dapat disimpulkan bahwa pada uji validitas diketahui 8 pernyataan dalam kuesioner Sikap Nasabah dinyatakan valid, karena $r_{h i t u n g}>r_{\text {tabel }}$.

\subsection{Uji Reliabilitas}

\section{Uji Reliabilitas Persepsi}

Uji reliabilitas ini dilakukan untuk mengetahui nilai cronbach's alpa suatu variabel dengan menggunakan IBM SPSS Statistics 23 untuk melihat nilai reliabilitas terhadap Persepsi dapat dilihat pada tabel berikut:

\section{Tabel 6 Uji Reliabilitas Persepsi}

Reliability Statistics 
Persepsi dan Preferensi terhadap Sikap Nasabah Pembiayaan Musyarakah...

\begin{tabular}{|r|r|}
\hline Cronbach's Alpha & N of Items \\
\hline
\end{tabular}

Sumber: Hasil output SPSS for windows versi 23

Berdasarkan tabel diatas diperoleh data uji reliabilitas pada cronbach's alpa menunjukkan 0,704 sehingga dapat dinyatakan reliabilitas tinggi (Sugiyono, 2016).

\section{Uji Reliabilitas Preferensi}

Uji reliabilitas dilakukan untuk mengetahui nilai cronbach's alpa suatu variabel dengan menggunakan IBM SPSS Statistics 23 untuk melihat nilai reliabilitas terhadap Preferensi dapat dilihat pada tabel berikut:

\section{Tabel 7 Uji Reliabilitas Preferensi}

Reliability Statistics

\begin{tabular}{|lr|r|}
\hline Cronbach's Alpha & N of Items \\
\hline & .613 & \\
\hline
\end{tabular}

Sumber: Hasil output SPSS for windows versi 23

Berdasarkan tabel diatas diperoleh data uji reliabilitas pada cronbach's alpa menunjukkan 0,613 sehingga dapat dinyatakan reliabilitas moderat (Sugiyono, 2016).

\section{Uji Reliabilitas Sikap Nasabah}

Adapun uji reliabilitas Sikap Nasabah dalam penelitian ini terdapat pada tabel berikut:

Tabel 8 Uji Reliabilitas Sikap Nasabah

$$
\text { Reliability Statistics }
$$

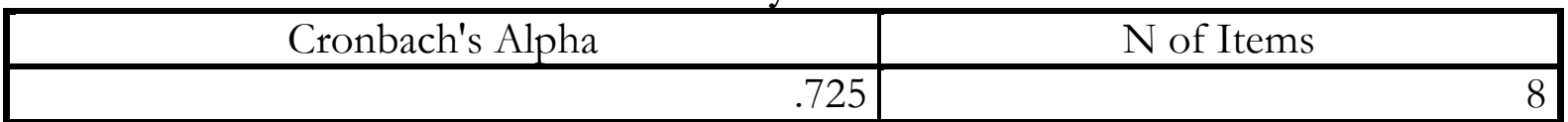

Sumber: Hasil output SPSS for windows versi 23

Berdasarkan pada tabel diatas diperoleh data uji reliabilitas pada cronbach's alpa menunjukkan 0,725 sehingga dapat dinyatakan reliabilitas tinggi (Sugiyono, 2016).

\subsection{Uji Asumsi Klasik}

\section{Uji Normalitas}

Data yang normal memiliki signifikan $>0,05$. Teknik yang digunakan peneliti antara lain Normal Probability Plot dan table uji Kolmogrov-smirnov untuk memperjelas dengan angka.

Tabel 9 Uji Normalitas

One-Sample Kolmogorov-Smirnov Test

\begin{tabular}{|ll|r|}
\hline & & \multicolumn{1}{|c|}{ Unstandardized } \\
Residual \\
\hline N & Mean & 53 \\
Normal Parameters ${ }^{\mathrm{a}, \mathrm{b}}$ & Std. Deviation & .0000000 \\
Most Extreme Differences & Absolute & 2.38749742 \\
& Positive & .104 \\
& Negative & .068 \\
Test Statistic & & -.104 \\
& & .104
\end{tabular}


Asymp. Sig. (2-tailed) $.200^{c, d}$

a. Test distribution is Normal.

b. Calculated from data.

c. Lilliefors Significance Correction.

$\mathrm{d}$. This is a lower bound of the true significance.

Sumber: hasil output SPSS for windows versi 23

Berdasarkan tabel diatas, diperoleh nilai signifikansi sebesar $0.200>0.05$. artinya, data penelitian berdistribusi normal karena signifikansi lebih besar dari 0.05. Maka uji normalitas terpenuhi dan analisis regresi dapat dilakukan.

\section{Uji Multikolinieritas}

Uji Multikolinieritas bertujuan mengetahui ada atau tidaknya variabel bebas yang memiliki kemiripan dengan variabel bebas lain dalam satu model. Model regresi yang baik seharusnya tidak memiliki kemiripan diantara variabel bebas.

Tabel 10 Uji Multikolinieritas

Coefficients $^{\text {a }}$

\begin{tabular}{|c|c|c|c|c|c|c|c|}
\hline \multirow[b]{2}{*}{ Model } & \multicolumn{2}{|c|}{$\begin{array}{l}\text { Unstandardized } \\
\text { Coefficients }\end{array}$} & \multirow{2}{*}{$\begin{array}{c}\begin{array}{c}\text { Standardized } \\
\text { Coefficients }\end{array} \\
\text { Beta } \\
\end{array}$} & \multirow[b]{2}{*}{$\mathrm{t}$} & \multirow[b]{2}{*}{ Sig. } & \multicolumn{2}{|c|}{$\begin{array}{c}\text { Collinearity } \\
\text { Statistics } \\
\end{array}$} \\
\hline & B & $\begin{array}{l}\text { Std. } \\
\text { Error }\end{array}$ & & & & Tolerance & VIF \\
\hline 1 (Constant) & 10.799 & 4.939 & & 2.186 & .034 & & \\
\hline Persepsi & .564 & .241 & .314 & 2.337 & .023 & .789 & 1.268 \\
\hline Preferensi & .471 & .203 & .312 & 2.320 & .024 & .789 & 1.268 \\
\hline
\end{tabular}

a. Dependent Variable: Sikap

Sumber: hasil output SPSS for windows versi 23

Berdasarkan hasil perhitungan uji multikolinieritas diatas diketahui bahwa nilai Variance Inflation Factor (VIF) sebesar 1.268 dan nilai tolerance sebesar 0.789. Hal ini menandakan bahwa tidak terjadi multikolinieritas antara variabel bebas dalam penelitian ini karena nilai VIF $1.268 \leq 10$ dan nilai tolerance $0.789 \geq 0.1$. Maka dapat disimpulkan bahwa tidak terdapat multikolinieritas dan model regresi layak untuk dipakai.

\subsection{STATISTIK DESKRIPTIF}

Analisis deskriptif merupakan alat uji analisis yang digunakan untuk memaparkan atau menggambarkan data yang terkumpul agar mudah dipahami. Berikut analisis deskriptif mengenai persepsi, preferensi, dan sikap nasabah pembiayan musyarakab pada BRI Syariah KC Suniaraja Bandung

\section{Tabel 11. Statistik Deskriptif}

Descriptive Statistics

\begin{tabular}{|l|r|r|r|r|r|r|r|}
\hline & $\mathrm{N}$ & Range & Minimum & Maximum & Mean & $\begin{array}{c}\text { Std. } \\
\text { Deviation }\end{array}$ & Variance \\
\hline Persepsi X1 & 53 & 7 & 13 & 20 & 17.38 & 1.496 & 2.239 \\
Preferensi X2 & 53 & 11 & 18 & 29 & 25.42 & 1.781 & 3.171 \\
Sikap & 53 & 15 & 22 & 37 & 32.57 & 2.685 & 7.212 \\
Nasabah Y & & & & &
\end{tabular}




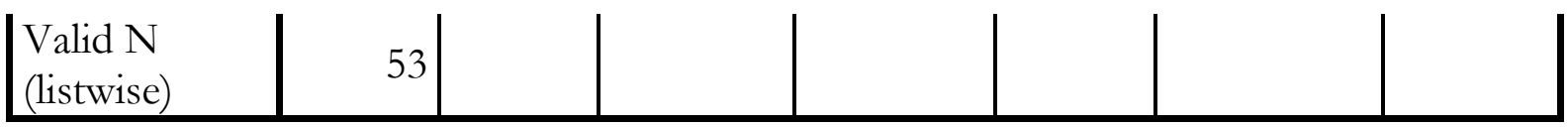

Sumber: hasil output SPSS for windows versi 20

Berdasarkan tabel diatas menunjukkan bahwa $\mathrm{N}$ atau jumlah data setiap variabel yang valid berjumlah 53, dari 53 data sampel sikap nasabah, nilai minimum sebesar 0,22, nilai maksimum 0,37 , nilai mean sebesar 32,57, serta nilai standar deviasi sebesar 2,685 yang artinya nilai mean lebih besar dari nilai standar sehingga penyimpangan data yang terjadi rendah, maka penyebaran nilainya merata. Persepsi dari 53 buah sampel diketahui bahwa nilai minimum sebesar 0,13 , nilai maksimum 0,20 , nilai mean sebesar 17,38 , serta nilai standar deviasi sebesar 1,496 yang artinya nilai mean lebih besar dari nilai standar sehingga penyimpangan data yang terjadi rendah, maka penyebaran nilainya merata. Preferensi dari 53 buah sampel diketahui bahwa nilai minimum sebesar 0,18, nilai maksimum 0,29, nilai mean sebesar 25,42, serta nilai standar deviasi sebesar 1,781 yang artinya nilai mean lebih besar dari nilai standar sehingga penyimpangan data yang terjadi rendah, maka penyebaran nilainya merata. standar deviasi sebesar 7.07404 dengan nilai minimum sebesar 3.53 dan nilai maksimum 25.14.

\subsection{Pengaruh Persepsi Terhadap Sikap Nasabah Pembiayaan Musyarakah}

Perkembangan perbankan syariah seiring waktu semakin berkembang pesat. Kemajuan teknologi yang juga diadopsi oleh perbankan syariah juga membuat bank syariah dilirik dalam melakukan transaksi keuangan, seperti pembayaran e-commerce, top up e-wallet dan Fintech. (Rumondang, Sudirman, Effendy, Simarmata, \& Agustin, 2019) Namun sebagai lembaga yang bernafaskan syariah maka transaksi keuangan sesuai dengan ajaran Islam dan jauh dari berbagai bentuk transaksi ribawi.

Meningkatnya perkembangan perbankan syariah dan animo masyarakat dalam bertransaksi di bank syariah, menunjukkan juga bertambahnya nasabah bank syariah. Keinginan dan kecenderungan masyarakat menjadi nasabah perbankan syariah sangat variatif bentuknya, diantaranya adalah persepsi. Persepsi merupakan proses yang dilakukan seseorang untuk memahami setiap informasi yang didapatkan melalui indera yang ada ditubuhnya, kemudian akan direpresentasikan untuk dilakukan. Penjelasan ini menunjukkan bahwa salah satu fungsi adalah untuk membantu orang memahami setiap informasi yang datang dari luar indera (Sarwono, 2004)

Berdasarkan hasil analisis, dapat diketahui bahwa persepsi berpengaruh terhadap sikap nasabah pembiayaan musyarakah pada BRI Syariah KCP Suniaraja. Hasilnya dapat dilihat pada analisis regresi, hasil uji korelasi pearson product moment, uji koefisien determinasi, dan uji t. Hasil uji regresi linear sederhana menunjukkan hasil berikut ini:

Tabel 12. Analisis Regresi Linier Persepsi terhadap Sikap Nasabah

\begin{tabular}{|c|c|c|c|c|c|}
\hline & \multicolumn{2}{|c|}{$\begin{array}{c}\text { Unstandardized } \\
\text { Coefficients }\end{array}$} & \multirow{2}{*}{$\begin{array}{c}\text { Standardized } \\
\text { Coefficients } \\
\text { Beta }\end{array}$} & \multirow[b]{2}{*}{$\mathrm{t}$} & \multirow[b]{2}{*}{ Sig. } \\
\hline Model & $\mathrm{B}$ & Std. Error & & & \\
\hline $1 \quad$ (Constant) & 18.289 & 3.896 & & 4.694 & .000 \\
\hline Persepsi (X1) & .822 & .223 & .458 & 3.678 & .001 \\
\hline
\end{tabular}


a. Dependent Variable: Sikap Nasabah (Y)

Sumber: hasil output SPSS for windows versi 20

Berdasarkan tabel regresi sederhana di atas, yaitu konstanta a sebesar 18.289 dan koefisien b sebesar $\mathbf{0 . 8 2 2}$. Berdasarkan hasil tersebut maka diperoleh persamaan regresi sebagai berikut:

$$
\begin{gathered}
Y=a+b X_{1} \\
\text { Sikap Nasabah= 18.289 }+0.822 \text { Persepsi }
\end{gathered}
$$

Berdasarkan persamaan regresi linier sederhana tersebut, diperoleh hasil nilai konstanta $(\alpha)$ yaitu 18.289 menunjukkan bahwa nilai sikap nasabah pada saat persepsi bernilai nol atau tetap, yaitu sebesar 4.690 dan bernilai positif. Selanjutnya, variabel persepsi memiliki nilai koefisien sebesar 0,822 artinya setiap kenaikan persepsi sebesar satu-satuan maka akan diikuti dengan kenaikan sikap nasabah sebesar 0.822. Koefisien regresi b bernilai positif, artinya telah terjadi hubungan antara persepsi dan sikap nasabah. Semakin tinggi nilai persepsi maka sikap nasabah akan meningkat atau semakin baik.

Untuk mengetahui seberapa besar kontribusi pengaruh persepsi terhadap sikap nasabah dapat ditunjukkan dengan menggunakan hasil perhitungan SPSS versi 23 yaitu koefisien determinasi.

Tabel 13. Analisis Koefisien Determinasi Persepsi terhadap Sikap Nasabah Model Summary

\begin{tabular}{|l|r|r|r|r|}
\hline Model & $\mathrm{R}$ & R Square & Adjusted R Square & \multicolumn{2}{|c|}{$\begin{array}{c}\text { Std. Error of the } \\
\text { Estimate }\end{array}$} \\
\hline 1 & $.457^{\mathrm{a}}$ & .209 & .193 & 2.412 \\
\hline
\end{tabular}

a. Predictors: (Constant), Preferensi $\left(\mathrm{X}_{2}\right)$

b. Dependent Variable: Sikap Nasabah (Y)

Sumber: hasil output SPSS for windows versi 20

Berdasarkan tabel diatas dapat diketahui nilai koefisien determinasi $\left(\mathrm{R}^{2}\right)$ yang ditunjukan sebesar 0,209 atau 20.9\%. Hal ini meunjukkan bahwa Sikap Nasabah dipengaruhi oleh variabel lain yang tidak diteliti sebesar $79.1 \%$ yang tidak termasuk dalam penelitian ini.

Dan terakhir, untuk mengetahui pengaruh persepsi terhadap sikap nasabah pembiayaan musyarakah, dilakukan melalui uji t berikut hasil yang diperoleh:

Tabel 14. Analisis Uji t Persepsi terhadap Sikap Nasabah

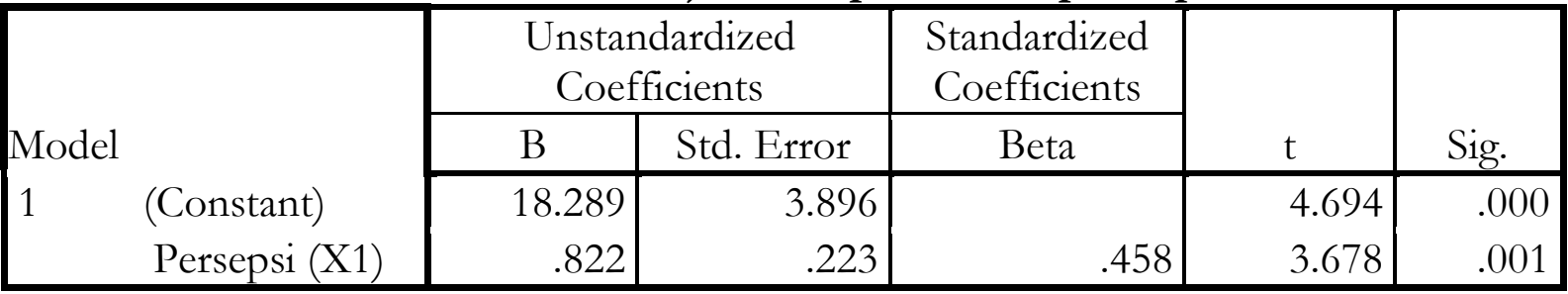

a. Dependent Variable: Sikap Nasabah (Y)

Berdasarkan table dijelaskan bahwa pengaruh variabel Persepsi terhadap Sikap didapatkan nilai thitung sebesar 3,678 sedangkan $t_{\text {tabel }}$ sebesar 1,675 atau thitung $>t_{\text {tabel }}$ dan tingkat signifikansi 0,001 $<0,05$ dengan demikian dapat disimpulkan bahwa $\mathrm{H}_{0}$ ditolak dan menerima $\mathrm{H}_{1}$ artinya Persepsi berpengaruh secara signifikan terhadap Sikap Nasabah. 
Hasil penelitian ini merupakan temuan awal yang diteliti, peneliti tidak dapat menemukan penelitian serupa yang dapat menjadi kerangka acuan. Sehingga penelitian ini berimplikasi pada BRI Syariah KCP Suniaraja. bahwa persepsi berpengaruh terhadap peningkatan sikap nasabah pembiayaan musyarakah. Selain itu juga penelitian ini dapat menjadi bahan pertimbangan bagi perusahaan lain yang sejenis untuk memperhatikan persepsi nasabah mereka karena persepsi dipengaruhi oleh banyak faktor seperti pengetahuan dan kebutuhan seseorang dan lain sebagainya. Terakhir penelitian ini dapat menjadi kerangka acuan bagi peneliti selanjutnya yang akan mengembangkan penelitian yang sama.

\subsection{Pengaruh Preferensi Terhadap Sikap Nasabah Pembiayaan Musyarakah}

Preferensi menurut definisi Kotler dan Keller (2009) ialah sikap dari konsumen pada pilihan produknya setelah melakukan penyaringan dan evaluasi pada beragam produk yang ada (Kotler dan Keller, 2009). Kemudian menurut Frank (2011), proses mengurutkan suatu produk menurut kriteria tertentu untuk dikonsumsi lalu mendapatkan preferensi dari produk atua jasa tersebut.

Preferensi menjadi sangat penting bagi bank, karena akan berkaitan dengan strategi pemasaran yang cocok agar dapat bermanfaat dan bertahan lama. Dengan demikian, bank dapat bersaing dan melakukan ekspansi pasar karena mengetahui keinginan konsumen atau nasabah. Hal ini karena, preferensi yang banyak pada calon nasabah akan membantuk mereka untuk menimbang dan memustuskan apakah akan menjadi nasabah atau tidak. Banyak sekali faktor yang menentukan preferensi seseorang, diantaranya pendidikan, demografi, usia, lingkungan sosial dan lainnya. (Simamora B. , 2004)

Berdasarkan hasil analisis, dapat diketahui bahwa preferensi terhadap sikap nasabah pembiayaan musyarakah pada BRI Syariah KCP Suniaraja. berpengaruh signifikan secara parsial. Hasilnya dapat dilihat pada analisis regresi, hasil uji korelasi pearson product moment, uji koefisien determinasi, dan uji t. Hasil uji regresi linear sederhana menunjukkan hasil berikut ini.

Tabel 15. Analisis Regresi Linier Sederhana Preferensi terhadap Sikap Nasabah Coefficients ${ }^{a}$

\begin{tabular}{|c|c|c|c|c|c|c|}
\hline \multirow{2}{*}{\multicolumn{2}{|c|}{ Model }} & \multicolumn{2}{|c|}{$\begin{array}{l}\text { Unstandardized } \\
\text { Coefficients }\end{array}$} & \multirow{2}{*}{$\begin{array}{c}\text { Standardized } \\
\text { Coefficients } \\
\text { Beta }\end{array}$} & \multirow[b]{2}{*}{$\mathrm{t}$} & \multirow[b]{2}{*}{ Sig. } \\
\hline & & B & Std. Error & & & \\
\hline 1 & (Constant) & 15.062 & 4.787 & & 3.147 & .003 \\
\hline & $\begin{array}{l}\text { Preferensi } \\
(\mathrm{X} 2)\end{array}$ & .689 & .188 & .457 & 3.666 & .001 \\
\hline
\end{tabular}

a. Dependent Variable: Sikap Nasabah (Y)

Sumber: hasil output SPSS for windows versi 20 
Berdasarkan tabel regresi sederhana di atas, yaitu konstanta a sebesar 15.062 dan koefisien b sebesar 0.689. Berdasarkan hasil tersebut maka diperoleh persamaan regresi sebagai berikut:

$$
\begin{gathered}
Y=a+b X_{1} \\
\text { Sikap Nasabah= 15.062 }+0.689 \text { Persepsi }
\end{gathered}
$$

Berdasarkan persamaan regresi linier sederhana tersebut, diperoleh hasil nilai konstanta $(\alpha)$ yaitu 15.062 menunjukkan bahwa nilai sikap nasabah pada saat preferensi bernilai nol atau tetap, yaitu sebesar 15.062 dan bernilai positif. Selanjutnya, variabel preferensi memiliki nilai koefisien sebesar 0,689 artinya setiap kenaikan preferensi sebesar satu-satuan maka akan diikuti dengan kenaikan sikap nasabah sebesar 0.689. Koefisien regresi b bernilai positif, artinya telah terjadi hubungan antara preferensi dan sikap nasabah. Semakin tinggi nilai preferensi maka sikap nasabah akan meningkat atau semakin baik.

Untuk mengetahui seberapa besar kontribusi pengaruh preferensi terhadap sikap nasabah dapat ditunjukkan dengan menggunakan hasil perhitungan SPSS versi 23 yaitu koefisien determinasi.

Tabel 16. Analisis Koefisien Determinasi Preferensi terhadap Sikap Nasabah Model Summaryb

\begin{tabular}{|l|r|r|r|r|}
\hline Model & $\mathrm{R}$ & R Square & Adjusted R Square & \multicolumn{2}{|c|}{$\begin{array}{c}\text { Std. Error of the } \\
\text { Estimate }\end{array}$} \\
\hline 1 & $.457 \mathrm{a}$ & .209 & .193 & 2.412 \\
\hline
\end{tabular}

a. Predictors: (Constant), Preferensi $\left(\mathrm{X}_{2}\right)$

b. Dependent Variable: Sikap Nasabah (Y)

Sumber: hasil output SPSS for windows versi 20

Berdasarkan tabel diatas dapat diketahui nilai koefisien determinasi $\left(\mathrm{R}^{2}\right)$ yang ditunjukan sebesar 0,209 atau 20,9\%. Hal ini menunjukkan bahwa sikap nasabah dipengaruhi oleh variabel lain yang tidak diteliti sebesar 79,1\% yang tidak termasuk dalam penelitian ini

Untuk mengetahui pengaruh preferensi secara parsial terhadap sikap nasabah, dilakukan dengan uji t:

\section{Tabel 17. Analisis Uji t Preferensi terhadap Sikap Nasabah}

\begin{tabular}{|c|c|c|c|c|c|c|}
\hline \multirow{2}{*}{\multicolumn{2}{|c|}{ Model }} & \multicolumn{2}{|c|}{$\begin{array}{l}\text { Unstandardized } \\
\text { Coefficients }\end{array}$} & \multirow{2}{*}{$\begin{array}{c}\text { Standardized } \\
\text { Coefficients }\end{array}$} & \multirow[b]{2}{*}{$\mathrm{t}$} & \multirow[b]{2}{*}{ Sig. } \\
\hline & & B & Std. Error & & & \\
\hline \multirow[t]{2}{*}{1} & (Constant) & 15.062 & 4.787 & & 3.147 & .003 \\
\hline & $\begin{array}{l}\text { Preferensi } \\
\text { (X2) }\end{array}$ & .689 & .188 & .457 & 3.666 & .001 \\
\hline
\end{tabular}

Coefficients $^{\text {a }}$

a. Dependent Variable: Sikap Nasabah (Y)

Sumber: hasil output SPSS for windows versi 20 
Berdasarkan tabel dapat dilihat bahwa pengaruh variabel Preferensi terhadap Sikap didapatkan nilai thitung sebesar 3,666 sedangkan $t_{\text {tabel }}$ sebesar 1,675 atau thitung $>t_{\text {tabel }}$ dan tingkat signifikansi $0,001<0,05$ dengan demikian dapat disimpulkan bahwa $\mathrm{H}_{0}$ ditolak dan menerima $\mathrm{H}_{1}$ artinya Preferensi berpengaruh secara signifikan terhadap Sikap Nasabah.

Unsur pembentuk preferensi calon konsumen ialah persepsi dari sebuah produk atau jasa. Persepsi yang ada dibenak calon konsumen akan menghasilkan preferensi menurut mereka masing-masing. Misalnya, pengetahuan atau wawasan keilmuan tentang perbankan syariah, fasilitas memadai, dan keaktifan karyawan dapat mempengaruhi konsumen sehingga membentuk preferensi calon konsumen. Dikarenakan masyarakat Indonesia sangatlah banyak dan tersebar luas sehingga menimbulkan preferensi yang berbeda-beda, kemudian keinginan, dan kebutuhan yang juga berbeda. (Amri, Qurratul'aini, \& Julianty, 2018)

Karakteristik nasabah dalam perbankan menjadi preferensi sendiri yang tidak bisa dilepaskan jika menilik di BRI Syariah KCP Suniaraja. Karakteristik yang ada pada masing-masing nasabah akan membantunya membentuk preferensi (Simamora, 2004). Seperti yang telah disebutkan, pendidikan, usia dan demografi pada masing-masing calon nasabah membuat mereka unik dan membentuk preferensi sendiri.

Karena itu, dalam penelitian ini kajian terhadap perbedaan preferensi nasabah terhadap sikap nasabah pembiayaan musyarakah dinilai perlu dilakukan. Setidaknya informasi tersebut dapat menjadi masukan bagi pihak manajemen BRI Syariah KCP Suniaraja dalam mengetahui preferensi nasabah terhadap sikap nasabah pembiayaan yang mereka tawarkan kepada masyarakat.

Hasil penelitian ini merupakan temuan awal yang diteliti, peneliti tidak dapat menemukan penelitian serupa yang dapat menjadi kerangka acuan. Sehingga penelitian ini berimplikasi pada BRI Syariah KCP Suniaraja. bahwa preferensi berpengaruh terhadap peningkatan sikap nasabah pembiayaan musyarakah. Selain itu juga penelitian ini dapat menjadi bahan pertimbangan bagi perusahaan lain yang sejenis untuk memperhatikan preferensi nasabah mereka karena preferensi dipengaruhi oleh banyak faktor seperti kebudayaan, demografi, umur, kelas sosial dan lain sebagainya. Terakhir penelitian ini dapat menjadi kerangka acuan bagi peneliti selanjutnya yang akan mengembangkan penelitian yang sama.

\subsection{Pengaruh Persepsi dan Preferensi Terhadap Sikap Nasabah Pembiayaan Musyarakah}

Menurut Sumarwan (2011), sikap (attitudes) konsumen adalah faktor penting yang akan mempengaruhi keputusan konsumen. Konsep sikap sangat terkait dengan konsep kepercayaan (belief) dan perilaku (behavior). Sikap merupakan ungkapan perasaan konsumen tentang suatu objek apakah disukai atau tidak, dan sikap juga bisa menggambarkan kepercayaan konsumen terhadap berbagai atribut dan manfaat dari objek tersebut. Kepercayaan konsumen adalah pengetahuan konsumen mengenai suatu objek, atributnya, dan manfaatnya. (Sumarwan, 2011)

Hasilnya dapat dilihat pada analisis regresi, uji koefisien determinasi, dan uji F. Hasil uji regresi berganda menunjukkan hasil berikut ini:

Tabel 18. Regresi Linier Berganda

\section{Coefficients $^{\mathrm{a}}$}




\begin{tabular}{|c|c|c|c|c|c|c|}
\hline \multirow{2}{*}{\multicolumn{2}{|c|}{ Model }} & \multicolumn{2}{|c|}{$\begin{array}{c}\text { Unstandardized } \\
\text { Coefficients }\end{array}$} & \multirow{2}{*}{$\begin{array}{c}\text { Standardized } \\
\text { Coefficients }\end{array}$} & \multirow[b]{2}{*}{$\mathrm{t}$} & \multirow[b]{2}{*}{ Sig. } \\
\hline & & $\mathrm{B}$ & Std. Error & & & \\
\hline \multirow[t]{3}{*}{1} & (Constant) & 10.799 & 4.939 & & 2.186 & .034 \\
\hline & Persepsi (X1) & .564 & .241 & .314 & 2.337 & .023 \\
\hline & Preferensi (X2) & .471 & .203 & .312 & 2.320 & .024 \\
\hline
\end{tabular}

a. Dependent Variable: Sikap Nasabah (Y)

Sumber: hasil output SPSS for windows versi 20

Berdasarkan tabel regresi berganda di atas, yaitu konstanta a sebesar 10.799, b1 sebesar 0.564 dan $b_{2}$ sebesar 0.471 Berdasarkan hasil tersebut maka diperoleh persamaan regresi linier berganda sebagai berikut:

$$
\mathbf{Y}=\mathbf{a}+\mathbf{b}_{1} \mathbf{X}_{1}+\mathbf{b}_{2} \mathbf{X}_{2}
$$

\section{Sikap nasabah $=10.799+0.564$ Persepsi +0.471 Preferensi}

Berdasarkan persamaan regresi linier berganda tersebut, diperoleh hasil, nilai konstanta $(\alpha)$ yaitu 10.799 menunjukkan bahwa nilai sikap nasabah pada saat persepsi dan preferensi bernilai 0 (nol) dan sikap nasabah bernilai positif, yaitu sebesar 10.799 . Koefisien regresi b1 untuk persepsi bernilai positif sebesar 0.564 , artinya setiap kenaikan persepsi sebesar satu-satuan maka akan diikuti dengan kenaikan sikap nasabah sebesar 0.564. Koefisien regresi $b_{1}$ bernilai positif, artinya telah terjadi hubungan antara persepsi dan sikap nasabah. Semakin tinggi nilai persepsi maka sikap nasabah akan meningkat. Selanjutnya, Koefisien regresi $b_{2}$ untuk preferensi bernilai positif sebesar 0.471, menunjukkan bahwa setiap kenaikan preferensi sebesar satu-satuan maka akan menaikkan sikap nasabah sebesar $\mathbf{0 . 4 7 1}$. Koefisien regresi $\mathrm{b}_{2}$ bernilai positif, artinya telah terjadi hubungan antara preferensi dan sikap nasabah. Semakin tinggi nilai preferensi maka sikap nasabah akan meningkat.

Untuk mengetahui seberapa besar pengaruh persepsi dan preferensi terhadap sikap nasabah dapat diperkirakan dengan menggunakan hasil perhitungan SPSS versi 23.

Tabel 19. Koefisien Determinasi Persepsi dan Preferensi terhadap Sikap Nasabah Model Summary

\begin{tabular}{|c|c|c|c|c|}
\hline Model & $\mathrm{R}$ & R Square & Adjusted R Square & $\begin{array}{c}\text { Std. Error of the } \\
\text { Estimate }\end{array}$ \\
\hline 1 & $.535^{\mathrm{a}}$ & .286 & .258 & 2.313 \\
\hline
\end{tabular}

a. Predictors: (Constant), Preferensi (X2), Persepsi (X1)

a. Predictors: (Constant), ROCE (X1), ROE (X2)

Sumber: hasil output SPSS for windows versi 20

Berdasarkan tabel diatas dapat diketahui nilai koefisien determinasi $\left(\mathrm{R}^{2}\right)$ yang ditunjukkan sebesar 0,286 atau 28,6\%. Hal ini menunjukkan bahwa Sikap Nasabah dipengaruhi oleh variabel lain yang tidak diteliti sebesar $71,4 \%$ yang tidak termasuk dalam penelitian ini.

Terakhir, untuk melihat pengaruh secara simultan yang ditimbulkan oleh persepsi dan preferensi terhadap sikap nasabah pembiayaan musyarakah secara simultan, maka dianalisis menggunakan Uji F. Hasil uji F menunjukkan:

Tabel 20. Analisis Uji F Persepsi dan Preferensi terhadap Sikap Nasabah ANOVAa 


\begin{tabular}{|c|c|c|c|c|c|c|}
\hline & & $\begin{array}{l}\text { Sum of } \\
\text { Squares }\end{array}$ & df & $\begin{array}{l}\text { Mean } \\
\text { Square }\end{array}$ & $\mathrm{F}$ & Sig. \\
\hline \multirow[t]{3}{*}{1} & Regression & 107.428 & 2 & \multirow{3}{*}{$\begin{array}{r}53.714 \\
5.352\end{array}$} & \multirow[t]{3}{*}{10.037} & \multirow[t]{3}{*}{$.000^{\mathrm{b}}$} \\
\hline & Residual & 267.591 & 50 & & & \\
\hline & Total & 375.019 & 52 & & & \\
\hline
\end{tabular}

a. Dependent Variable: Sikap Nasabah (Y)

b. Predictors: (Constant), Preferensi (X2), Persepsi (X1)

Sumber: hasil output SPSS for windows versi 20

Berdasarkan tabel diatas menunjukkan bahwa nilai $\mathrm{F}_{\text {hitung }}$ sebesar 10.037 dengan nilai signifikansi sebesar 0,000. Karena tingkat signifikansinya lebih kecil dari 0,05 maka $\mathrm{H} 1$ diterima dengan nilai $\mathrm{F}_{\text {hitung }}>\mathrm{F}_{\text {tabel }}(10.037>3,18)$ sehingga dapat dikatakan bahwa Persepsi dan Preferensi secara simultan berpengaruh signifikan terhadap Sikap Nasabah di BRI Syariah KC Suniaraja Bandung.

Berdasarkan hasil penelitian yang telah diuraikan diatas, maka dapat diketahui baik secara parsial dan simultan persepsi dan preferensi memiliki pengaruh signifikan terhadap sikap nasabah pembiayaan musyarakah. Dimana dari hasil penelitian itu, ditemukan dari setiap kenaikan persepsi dan preferensi akan diikuti dengan kenaikan sikap nasabah pembiayaan musyarakah.

\section{Kesimpulan}

Berdasarkan hasil penelitian yang dilakukan mengenai pengaruh persepsi dan preferensi terhadap sikap nasabah pembiayaan musyarakah, dapat disimpulkan dalam tiga poin. Pertama, secara parsial persepsi berpengaruh terhadap sikap nasabah pembiayaan musyarakah BRI Syariah KCP Suniaraja di mana kontribusi pengaruhnya sebesar 21\%, dengan demikian hipotesis H1 diterima. Kedua, secara parsial preferensi berpengaruh juga terhadap sikap nasabah pembiayaan musyarakah BRI Syariah KCP Suniaraja dengan kontribusi pengaruh 20.9\%, sehingga hipotesis H2 diterima. Ketiga, secara simultan persepsi dan preferensi terhadap sikap nasabah pembiayaan musyarakah BRI Syariah KCP Suniaraja denngan kontribusi pengaruh 28.6\%, maka dari itu hipotesis H3 diterima. Pada akhirnya penelitian ini akan berkontribusi dalam analisis sikap nasabah pembiayaan musyarakah. Apabila ingin meningkatkan sikap nasabah pembiayaan musyarakah maka perlu kiranya untuk memperhatikan persepsi dan preferensi nasabah

\section{REFERENSI}

Kotler, P. (1997). Manajemen Pemasaran. Jakarta: Prehalindo.

Amri, K., Qurratul'aini, I., \& Julianty. (2018). Preferensi Nasabah Memilih Produk Pembiayaan Bank Aceh Syariah di Kota Banda Aceh. JURNAL SAMUDRA EKONOMI DAN BISNIS, VOL 9, NO 1, 31-41.

Ikatan Bankir Indonesia. (2015). Mengelola Bisnis Pembiayaan Bank Syariah. Jakarta: PT Gramedia Pustaka Umum.

Miftahuddin. (2019). Perbandingan Konsep Keuangan pada Bank Syariah dan Bank Konvensional. Journal of Education, Humaniora and Social Sciences (JEHSS).

Notoatmodjo, S. (2003). Pendidikan dan Perilaku Kesehatan . Jakarta: Rineka Cipta. 
Rumondang, A., Sudirman, A., Effendy, F., Simarmata, J., \& Agustin, T. (2019). Fintech: Inovasi Sistem Kenangan di Era Digital. Jakarta: Yayasan Kita Menulis.

Sari, W. (2020). Pengaruh Pembiayaan dengan Prinsip Jual Beli dan Pembiayaan dengan Prinsip Bagi Hasil terhadap Performa Bisnis PT Bank BRI Syariah. Jurnal Ekonomi, Keuangan, Perbankan dan Akuntansi .

Sarwono, S. W. (2004). Psikologi Remaja. Jakarta: CV Rajawali.

Setiadi, N. J. (2019). Perilaku Konsumen: Perspektif Kontemporer pada Motif, Tujuan, dan Keinginan Konsumen Edisi Ketiga (Vol. 3). Jakarta: Prenada Media.

Simamora, B. (2004). Panduan Riset Perilaku Konsumen. Jakarta: PT. Gramedia Pustaka Utama.

Siyoto, S. d. (2015). Dasar Metodologi Penelitian. Yogyakarta: Literasi Media Publishing.

Sugiyono. (2008). Metode Penelitian Pendidikan Pendekatan Kuantitatif, Kualitatif, dan R\&D. Bandung: Alfabeta.

Sugiyono. (2016). Metode Penelitian Kuantitatif, Kualitatif dan R\&D. Bandung: Alfabeta.

Sumarwan, U. (2011). Perilaku Konsumen Teori dan Penerapannya dalam Pemasaran. Bogor: Penerbit Ghalia Indonesia.

Wakhidah, N. d. (2012). Pembiayaan Musyarakah Dari Sisi Penawaran Pada Perbankan Syariah Di Indonesia. jurnal Ekonomi dan Bisnis Universitas Pekalongan. 